\title{
SERPINA7 Gene
}

National Cancer Institute

\section{Source}

National Cancer Institute. SERPINA7 Gene. NCI Thesaurus. Code C106000.

This gene plays a role in thyroid hormone binding. 